\title{
EU, TRADING AND HUMAN RIGHTS: CONSISTENT FRAMEWORK?
}

\author{
CAROLINA JIMÉNEZ SÁNCHEZ ${ }^{1}$
}

\begin{abstract}
The relationship between European Union and International Human Rights Law has not always been close. The global projection of the EU, specially, its interest in becoming a leader in international trade, is facing its negative impact in some territories, specially those affected by human rights violation or negation of fundamental rules of International Law, such as ius cogens self-determination of people. This paper will examine to what extend the practice of the European Union trading with occupying and administrative powers in some territories could jeopardise its compliance with its own values and principles.
\end{abstract}

Keywords: Human rights, Trading, self-determination, European Union, Occupied Territories, GSP.

Summary: 1. Introduction. 2. Protecting Human Rights while trading?. 3. Challengues and threads TRADING IN OCCUPIED TERRITORIES. 3.1. Human Rights in Western Sahara and trading with the occupying

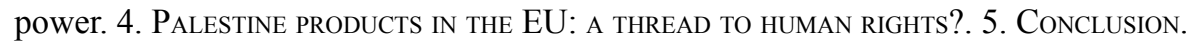

\section{INTRODUCTION}

This paper focuses on examining the current implications of the applicable rules and the practice developed by the European Union with respect to territories whose human rights are specially vulnerable. Those include non-self governing territories or territories with special or disputed status, but also an overview to the legal framework around trade and human rights in the EU. Its special relationship with the due protection of the Human Rights of these populations and their controversial alignment with the commercial relation need to be addressed, due to the recent development in this area regarding the case of Polisario Front before de CJEU.

There is a growing academic interest in the external action of the European Union. The desired leadership of the Union in the mediation of international conflicts makes it necessary to focus on its practice and its compliance with human rights. In any case, what happens in its relations with other territories, specifically with "disputed territories", must be analyzed from the point of view of its essential principles and values. As Kassoti shows, "the EU's practice in relation to the conclusion of trade agreements covering occupied territories has increasingly challenged the narrative of 'normative power Europe"'.

Likewise, it is necessary to underline that the carrying out of studies of this type have focused fundamentally on examining the practice of the European Union in a specific

\footnotetext{
${ }^{1}$ Lecturer in International Law and International Relations, University of Málaga, Spain (carolina@uma.es). This paper has been produced during a stay in the T.M.C Asser Intituut as a CLEER fellowship.
} 
conflict, so that the comparative analysis will yield new elements of analysis that will undoubtedly provide particular relevance in the examination of conflicts separately.

Territorial conflicts are particularly complex and their resolution requires a renewed perspective that continues to rely on the application of imperative norms of International Law, such as the self-determination of peoples and the necessary respect of Human Rights Law. It is not urgent to give the concept of self-determination a new meaning, but precisely to execute its essential meaning, with mechanisms for the peaceful resolution of conflicts of our time. This is where regional integration organizations become increasingly important, as their diplomatic, commercial and economic relations have a direct impact on the survival of these conflicts and also on their eventual solution.

The European Union is willing to became a human rights world-leader, as we as to continue developing its essential nature of commercial power. Nevertheless, trading with vulnerable territories imply some remarks on the agreements, such as human rights clauses and sustainable development concerns.

The articles focuses in the legal framework governing trade and human rights in the EU, as well as the international legal framework governing those vulnerable territories, arguing if its possible to reconcile these two objetives.

\section{Protecting Human Rights while trading?}

According to articles 3 (5) and 21 TEU the protection of human rights in the context of trade agreements is relevant if we consider also the inspiring principles and values of the European Union ${ }^{2}$. Moreover, a key rule in European Union law is constituted by the Charter of Fundamental Rights of the European Union and the principles for conducting agreements with third-party States always in the respect of the human rights (human rights clause) (Gómez Cosarnau, 2003 \& Der-Chin Horng 2003) (Fierro Elena and Eeckhout Piet, 2006). Article 21 of the Treaty on European Union states:

"The Union's action on the international scene shall be guided by the principles which have inspired its own creation, development and enlargement, and which it seeks to advance in the wider world: democracy, the rule of law, the universality and indivisibility of human

\footnotetext{
${ }^{2}$ Article 3 (5) TEU sets out: (...) "The Union shall uphold and promote its values and interests and contribute to the protection of its citizens. It shall contribute to peace, security, the sustainable development of the Earth, solidarity and mutual respect among peoples, free and fair trade, eradication of poverty and the protection of human rights, in particular the rights of the child, as well as to the strict observance and the development of international law, including respect for the principles of the United Nations Charter".

Article 21.1 TEU states: "The Union's action on the international scene shall be guided by the principles which have inspired its own creation, development and enlargement, and which it seeks to advance in the wider world: democracy, the rule of law, the universality and indivisibility of human rights and fundamental freedoms, respect for human dignity, the principles of equality and solidarity, and respect for the principles of the United Nations Charter and international law".
} 
rights and fundamental freedoms, respect for human dignity, the principles of equality and solidarity, and respect for the principles of the United Nations Charter and international law".

This principle assumes that the EU must guarantee consistency and effectiveness in its foreign relations practice. This implies, not only a formal position based on general statements, but an active role in defending its key principles for foreign action. Which should entail, where appropriate, the application of countermeasures and other actions when necessary. At the European Union level, this should be equivalent to the imposition of sanctions and restrictive measures that, throughout this study, will be explored in their existence or nonexistence.

As an instrument of this policy we have to underline the importance of the Guidelines on Human Rights to be used in dialogues with third countries. According to this instrument the EU should perform a real "human rights mainstreaming", integrating human rights and democratisation in all aspects of external action, where the first step os to decide to iniciate a human-rights specific dialogue with a third country, having into account some preliminary remarks.

Some decades before, in the first non-binding appearances of the human rights clause in international treaties with third States, such as Lomé I and Lomé II, the conditions imposed by the EU were not later an obstacle to continue with commercial relations or aid to the development, tending to become legally binding later through the so-called "Bulgarian clause"3.

Likewise, we must highlight the evolution of the practice of the European Communities with the so-called Generalized Scheme of Preferences for imports from developing countries (GSP), as well as the Technical and Financial Assistance Regulations developed. Development aid has been precisely one of the most important effects in the application of the so-called "Human Rights clause". A key nexus is stablished between development aid and trade, with the limits assimilated by the aforementioned clause.

In countries such as Zimbabwe or Haiti, this aid has been suspended due to the human rights clause. In the case of Haiti, through Council Regulation No. 1603, of June 24, 1993, regarding the imposition of an embargo on certain commercial operations between the European Community and the latter, which had a fluctuating path with various modifications supervening (García Junior, 2013).

With regard to Zimbabwe, the Common Position of the Council of 18 February 2002 on the adoption of restrictive measures should be highlighted. In this, sanctions are imposed on the Government of the country and consultations for trade agreement were abruptly concluded. The reason was the concern "about the laws recently approved in Zimbabwe, which, if applied, would seriously undermine the right to freedom of expression, assembly and association, in particular the Law of Public Order and Security and the Law of Modification of General Laws (since both violate the norms and conditions for free and fair

\footnotetext{
${ }^{3}$ Also known as the "negative conditionality clause", it has been used since 1995 in all international agreements concluded between the European Union and third States and implies their suspension if there is a serious violation of essential elements, including human rights.
} 
elections, agreed by the SADC parliamentarians in March 2001), as well as the legislation proposed to regulate the media"4. It thus highlights from past practice that the sole concern arising from the lack of protection of human rights has been sufficient cause to disrupt the EU's trade and diplomatic relations with certain states.

Another example of this trend is Cuba and its fluctuating diplomatic relations with the Union due to the lack of guarantees on the protection of Human Rights, which would occur from its Common Position of 1996. This has hindered their relations until the arrival of the Political Dialogue and Cooperation Agreement (ADPC) in 2016. Despite the complex relationship that the island currently maintains with the United States, and the difficulties that the tandem with Venezuela is going through, the commitment of the Due to a change in policies, the EU leads to the consolidation of economic relations that, despite the Common Position, had been taking place with European companies (mainly Spanish) for decades.

However, when the practice of the European Union with some of its priority partners is examined, human rights have not been considered as highly as in other territories, given the risk of jeopardizing bilateral relations. Suffice it to consider the EU's agreements with states that continuously violate human rights, such as the relations it has maintained with the GCC (Gulf Cooperation Council), whose member states include Saudi Arabia. The GCC benefited from a Generalised Scheme of Preferences until 2014 (Ayuso, 2017).

The human rights clause requires the parties to respect democratic principles and human rights provisions. More recently, the EU has also include the necessity to include labour and environmental standards, as a kind of "sustainable development" considerations.

Regarding the EU Human Rights Charter, we cannot consider that its scope is universal (Lenaerts, 2012), and the entire debate around this issue would need a separate analysis. But the coherence principle informs to do not contradict the own actions in external action. Even the article 2 TEU implies the promotion of human rights ad intra and ad extra, and article 21.2 establishes consolidation and support for democracy, the rule of law, the human rights and the principles of international law as objetictives in its foreign action.

The Human Rights and Democracy EU Strategic Framework and EU Action Plan (11417/12, 25 June 2012), stated that "the EU will promote human rights in all areas of its external action without exception. In particular, it will integrate the promotion of human rights into trade (...)", establishing a material obligation for the EU when affirms "The EU will place human rights at the centre of its relations with all third countries, including its strategic partners. While firmly based on universal norms, the EU's policy on human rights will be carefully designed for the circumstances of each country, in this light, the EU will continue to deepen its human rights dialogues and consultations with partner countries and will aim to ensure that these dialogues lead to results"s.

\footnotetext{
${ }^{4}$ Council Common Position of 18 February 2002 concerning restrictive measures against Zimbabwe OJ L 50, 21.2.2002,

${ }^{5}$ EU Strategic Framework and Action Plan on Human Rights and Democracy, Luxembourg, 25 June 2012 $11855 / 12$.
} 
The EU Common Commercial Policy is the perfect area to develop the ad extra human rights provisions and principles explained. The EU has currently used three kind of tools to make it possible:

1) bilateral free trade agreements

2) the regulation of certain product exports

3) the granting of generalized preferences to certain countries

So far, the EU has conducted over 40 trade agreements in more than 80 different countries $^{6}$. The Generalised Scheme of Preferences (GSP) try to offer preferential market access to lower and middle-icome countries, besides the bilateral agreements continue to included the so-called "human rights clause" since the 90's of the last century. Respect for human rights would constitute an essential element of the agreement and its lack of observance entailed the adoption of measures of different kinds that, ultimately, term, could suppose the termination of the same. The human rights clause is primarily included in political framework agreements, which should be referred to in subsequent trade agreements. Free trade agreements or more comprehensive association agreements with no framework agreement may include the human rights clause alongside the trade or cooperation provisions (Wahlqvist, 2021, 23).

To be added is the EU Council Regulation 2820/98, whose article 22 establishes theat the arrangements provided by the GSP may at any time be temporarily withdrawn in whole or in part, in circumstances such as the practice of any form of slavery, the export of godds made by prison labour or manifest cases of infringement of the objectives of international conventions ${ }^{7}$, further developed by the EU Council Regulation 2502/2001 .

\footnotetext{
${ }^{6} \mathrm{https}$ ://trade.ec.europa.eu/access-to-markets/en/non-eu-markets.

${ }^{7}$ Council Regulation (EC) No 2820/98 of 21 December 1998 applying a multiannual scheme of generalised tariff preferences for the period 1 July 1999 to 31 December 2001, Official Journal L 357, 30/12/1998 P. $0001-0112$. The following reason are included:

(a) practice of any form of slavery or forced labour as defined in the Geneva Conventions of 25 September 1926 and 7 September 1956 and International Labour Organisation Conventions No 29 and No 105;

(b) export of goods made by prison labour;

(c) manifest shortcomings in customs controls on export or transit of drugs (illicit substances or precursors), or failure to comply with international conventions on money laundering;

(d) fraud or failure to provide administrative cooperation as required for the verification of certificates of origin form A;

(e) in manifest cases of unfair trading practices on the part of a beneficiary country. The withdrawal shall be in full compliance with the WTO rules;

(f) manifest cases of infringement of the objectives of international conventions such as NAFO, NEAFC, ICCAT and NASCO concerning the conservation and management of fishery resources.

Temporary withdrawal shall not be automatic, but shall follow the procedural requirements laid down in the following Articles, including Article 26(3).

${ }^{8}$ Commission Regulation (EC) No 2535/2001 of 14 December 2001 laying down detailed rules for applying Council Regulation (EC) No 1255/1999 as regards the import arrangements for milk and milk products and opening tariff quotas Official Journal L 341, 22/12/2001 P. 0029 - 0069
} 
The Council modified the regime and approved, on June 27, 2005, The EU Regulation 980/2005 which was configured as a new framework ${ }^{9}$. The objective of this reform was to provide greater objectivity in the granting and withdrawal of GSP. This regulation eliminated the difference existing so far between special incentive regimes for the protection of labor rights and for the protection of the environment and created, outside the general regime, a special regime to stimulate sustainable development and governance (Janer Torrens, 2017). Article 16 of this regulation included the temporarily withdrawal of GSP for all or part of the products of a beneficiary country if there was a serious and systematic violation of the principles established in the sixteen conventions on human rights and labor rights. Recently, GSP in respect of certain products has been withdrawn temporarily to Cambodia, due to systematic and serious violation of principle laid down in the core human and labour rights UN/ILO Conventions ${ }^{10}$.

Subsequent ammendents to the GSP regulation continued with the EU Council Regulation 978/2012 ${ }^{11}$, adapting the tool to the new Lisbon treaty system. Still, the latest modification were introduced in $2021^{12}$, including Uzbekistan in the GSP.

Regarding the second tool, the EU limited trade implying some products that might contribute to severe human rights violation trhough the Regulation 1236/2005 ${ }^{13}$. Even thoug, the restraint of the regulation is only referred to "goods that could be used for the purpose of capital punishment or for the purpose of torture and other cruel, degrading or inhuman treatment or punishment, and in related technical assistance". The EU requires express authorisation when these goods might have another practical use than the referred. Decision on these kind of authorisation need to be taken in a caee-by-case basis.

In the same way, we have to consider the Common Position 2008/944/CFSP ${ }^{14}$, banning the technology and military equipment export licenses to countries that could use them for of internal repression violating the population human rights.

All these mechanisms try to contribute to human rights promotion while trading, rejecting at some extend the responsibility of the EU in some severe violations of Human Rights.

\footnotetext{
${ }^{9}$ Council Regulation (EC) No 980/2005 of 27 June 2005 applying a scheme of generalised tariff preferences. OJ L 169, 30.6.2005, p. 1-43

${ }^{10}$ Commission Delegated Regulation (EU) 2020/550 of 12 February 2020 amending Annexes II and IV to Regulation (EU) No 978/2012 of the European Parliament and of the Council as regards the temporary withdrawal of the arrangements referred to in Article 1(2) of Regulation (EU) No 978/2012 in respect of certain products originating in the Kingdom of Cambodia, C/2020/673.

${ }^{11}$ Regulation (EU) No 978/2012 of the European Parliament and of the Council of 25 October 2012 applying a scheme of generalised tariff preferences and repealing Council Regulation (EC) No 732/2008.

${ }^{12} \mathrm{https}$ ://eur-lex.europa.eu/legal-content/EN/TXT/?uri=CELEX\%3A02012R0978-20210410.

${ }^{13}$ COUNCIL REGULATION (EC) No 1236/2005 of 27 June 2005 concerning trade in certain goods which could be used for capital punishment, torture or other cruel, inhuman or degrading treatment or punishment. ${ }^{14}$ COUNCIL COMMON POSITION 2008/944/CFSP of 8 December 2008 defining common rules governing control of exports of military technology and equipment.
} 
Nevertheless, the difficulty lies in the interpretation of what can be considered a human right violation. Standarts introduced in the EU Council Regulation 980/2015 help to clarify what would be an obstacle to human rights promotion, improving the quality of the legal framework.

\section{Challengues AND THREADS TRADING IN OCCUPIED TERRITORIES}

In the special context of Non-Self-Governing Territories, the European Union, as a third party, has the obligation not to contribute to the occupation and respect the will of the people. This would imply trading. The aforemention Action Plan is more than clear regarding the European Neighbourhood Policy, claiming that "The EU will step up its effort to make best use of the human rights clause in political framework agreements with third countries". The Action Plan and the hole sense of the European Union Law makes unclear and inconsistent the practice developed in some territories, including Western Sahara, as the last colony in Africa, or Palestine.

It must be remembered that the International Court of Justice, in its Advisory Opinion on the Legal Consequences of the construction of a wall in the occupied Palestinian territory (2004) stated that all States are under the obligation of not recognizing the illegal situation resulting from the wall construction, "they are also under an obligation not to render aid or assistance in maintaining the situation created by such construction". In addition, the Opinion declared that the self-defence did not fit as an argument to justify the construction of the wall. Also, in accordance with what was already indicated by the Court in the Advisory Opinion on the Legal Consequences that the continuation of the presence of South Africa has for the States in Namibia, "Israel is bound to comply with its obligation to respect the right of the Palestinian people to self-determination and its obligations under international humanitarian law and international human rights law. "In essence, the construction of the wall entailed the violation of multiple norms of Human Rights and International Humanitarian Law, which resulted in a clear responsibility of the State (Israel) for illegal acts that the Court urged to repair, as evidenced in the Opinion "the construction of the wall in the Occupied Palestinian Territory has, inter alia, entailed the requisition and destruction of homes, businesses and agricultural holdings, the Court finds further that Israel has the obligation to make reparation for the damage caused to all the natural or legal person concerned ".

The International Court of Justice sustains that the States have the obligation, in addition to the aforementioned non-recognition of sovereignty in the occupied territory, of not helping to maintain the situation created with the construction of the wall, in addition to recognizing that Israel has violated rules of International Law that all States may be interested in protecting, as already stated in the Barcelona Traction case .

Besides, the exploitation of the natural resources of the territory of Western Sahara and other Non-Self-Governing territories might be carried out to the detriment of its inhabitants and may infringe their human rights., and that must be included in the regulation of GSP as an example. 
Even more when the exploitation of natural resources is conducted without consent and is not improving the situations of local people, affecting ius cogens rules as the selfdetermination of people. As Kassoti pointed out "the EU's practice in relation to the conclusion of trade agreements covering occupied territories has increasingly challenged the narrative of 'normative power Europe' (Kassoti, 2017) and the practice not solely involves Western Sahara. If one of the biggest challenges of International Law today is its fragmentation (Koskeniemi and Leino, 2002), this issue also affects Non-Self-Governing Territories. International Humanitarian Law provides key norms that should govern the behaviour of States when we talk about occupied territories, which for the purposes of this article are understood as those that have been illegally annexed (Wrange, 2015). Human Rights and International Criminal Law are also central to protecting these peoples not yet constituted in States, from the expansive force of an International Community in expansion. The imperatives of International Economic Law extend not only to the States, but of the International Organizations, over some people pending to confirm their status in the International Community.

The natural resources of these peoples are valuable elements for international macro-institutions. In the International Community is needed to attend to the international rules and principles that make the status of Non-Self-Governing territories "special" and "untouchable" since the time of decolonization and landmark UNGAR 1514 (XV).

\subsection{Human Rights in Western Sahara and trading with the occupying power}

European Union has emerged as another concerned party in Wester Sahara conflict, unwilling to become involved but committed to develop a commercial and political relationship with his principal partner in the MENA region, Morocco. This controversial and polarizing relationship could jeopardize the EU leading principles in its External Action, (i.e., human rights and the respect of the self-determination of people). This procedure could have an adverse effect, thereby contravening rather than reinforcing the Organization's values and previous practice in the EU concerning nonself-governing territories. The EU must ensure consistency and effectiveness in its external policy, which implies not only statements and declarations but an active role defending its key external principles. It shall mean countermeasures and other actions being applied (Wrange, 2017).

The human rights of Sahrawi people are being serioursly contested in the territory occupied by Morocco. As pointed out by numerous human rights activits and the last report of the UN Secretary General:

"OHCHR remained concerned about the continued trend of restrictions on the rights to freedom of expression, peaceful assembly and association in Western Sahara by Moroccan authorities. During the reporting period, OHCHR received reports of harassment, arbitrary arrest and sentencing of journalists, lawyers and human rights

defenders also received several reports about torture, ill-treatment and medical neglect in Moroccan prisons, with civil society organizations and lawyers advocating for 
the release during the COVID-19 pandemic of Sahrawi prisoners such as the Gdeim Izik group and a group of students"15.

This could be an key element to redefine the commercial policy developed with Morocco, in accordance with the allegued human rights mainstreaming in external action.

The relations between the EU and Morocco have had several phases and trade agreements since in 2000 the Euro-Mediterranean Agreement ${ }^{16}$ was adopted, establishing a greater approach in commercial relations, especially agricultural. In the development of this agreement, in 2005, a Plan of Action was accorded and, subsequently, the agreement for the liberalization of agricultural products and fishing by-products was signed in $2012^{17}$. As a result of this agreement, in the same year, Commission Implementing Regulation (EU) No. 812/2012 was adopted, modifying Council Regulation (EC) No. 747/2001 regarding quotas and tariffs for certain agricultural products and processed agricultural products, originating in Morocco.

Regarding the Western Sahara cases before EU Courts (C-104/16 and C-266/16), the elements of analysis are ground-breaking (Van Der Loo, 2018). It is hugely relevant that in both sentences the courts of the European Union interpreted the terms of the agreement differently. While the Judgment by the GTEU of 2015 understands the need to partially nullify the agreement by moving its object beyond Moroccan sovereignty, in the 2018 ruling it is assumed that the territory of Western Sahara is automatically outside the scope of the agreement, without having mediated a check on its implementation. This is amply demonstrated by the fact that the Council in 2017 authorised the Commission to re-negotiate a new agreement meeting these new circumstances ${ }^{18}$.

In fact, although in trading with the Kingdom of Morocco has become clear that the exclusion of Western Sahara territory has not been made categorically, the Court is precise in stating the interpretation: "the Partnership Agreement and the 2013 Protocol will be interpreted in the sense that the waters adjacent to the territory of Western Sahara are not

\footnotetext{
15 Situation concerning Western Sahara, Report of the Secretary General. Situation concerning Western Sahara. 23 September 2020. S/2020/938, párr. 69.

${ }^{16}$ Euro-Mediterranean Agreement establishing an association between the European Com- munities and their Member States, of the one part, and the Kingdom of Morocco, of the other part, OJ [2000] L70/2.

17 2012. /497/EU: Council Decision of 8 March 2012 on the conclusion of an Agreement in the form of an Exchange of Letters between the European Union and the Kingdom of Morocco concerning reciprocal liberalisation measures on agricultural products, processed agricultural products, fish and fishery products, the replacement of Protocols 1, 2 and 3 and their Annexes and amendments to the Euro-Mediterranean Agreement establishing an association between the European Communities and their Member States, of the one part, and the Kingdom of Morocco, of the other part.

${ }^{18}$ Recommendation for a Council Decision authorising the opening of negotiations on the adaptation of protocols to the Agreement between the European Union and the Kingdom of Morocco (ST 90932017 INIT 12) May 2017.
} 
included in the respective territorial areas of application of the Collaboration Agreement and the 2013 Protocol".

Thus, the Judgment in Case C-266/16 clarifies the interpretation that must be given to the territorial scope of the agreement, without explicitly excluding the territory of Western Sahara. The Protocol only refers to the fact that the activities will be carried out in the "Moroccan fishing zone", which clearly seems insufficient for an agreement concluded with a de facto administration State, a Non-Self-Governing Territory that assists the right of self-determination of the people and, therefore, the obligation of non-recognition and the subjection to the norms of occupation.

Nevertheless, the new agreement signed in 2018 does not guarantee the conservation of natural resources of Saharawi people. In 2019, Council Decision ${ }^{19}$ took into account the CJEU pronouncements admitting that "the practice of applying the trade preferences set out in the Association Agreement and its protocols on a de facto basis to products originating in Western Sahara could not, therefore, continue". The Council decided nonetheless to remain in opposition to the CJEU Judgements by adding the following sentence "The bilateral agreements between the European Union and Morocco can, however, be extended to cover products from Western Sahara under certain conditions, provided that the appropriate legal basis exists".

On the other hand, The CJEU pronouncements were much less clear when considering the international legal personality of Polisario Front. This National Liberation Movement legitimacy has been, notonly compromised, but denied the both pronouncements. According to International Law, Polisario is the legal and sole representative of Sahrawi people until Western Sahara territory can conclude the self-determination process. The legal status of the territory is still a Non-Self-Governing territory, and the Front is the legitimate representative of the Sahrawi people, as it is said in the UNSCR 2625 (XXV), the territory has a different status from the administrating power:

"The territory of a colony or other Non-Self-Governing Territory has, under the Charter, a status separate and distinct from the territory of the State administering it; and such separate and distinct status under the Charter shall exist until the people of the colony or Non-Self-Governing Territory have exercised their right of self-determination in accordance with the Charter, and particularly its purposes and principles".

Furthermore, following Cassese, national liberation movements have "the rights and obligations deriving from rules on treaty making. The existence of the power is evidenced by the numerous agreements various liberation movements have entered into

\footnotetext{
${ }^{19}$ COUNCIL DECISION establishing the position to be adopted on behalf of the Union in the Association Committee set up by the Euro-Mediterranean Agreement establishing an association between the European Communities and their Member States, of the one part, and the Kingdom of Morocco, of the other part, concerning the exchange of information with Morocco for the purpose of evaluating the impact of the agreement in the form of an Exchange of Letters on the amendment of the Euro-Mediterranean Agreement.
} 
on such matter" (Cassese, 2005). In fact, Front Polisario itself has signed international agreements, as the peace agreement reached with Mauritania in 1979.

This legal status is not considered by the Court clear enough to give procedural rights to Polisario. But still, it cannot be denied the right of any legal person directly concerned to institute proceeding to the Court, as it is said by article 263 para 4 of the Treaty in the Functioning of the European Union:

"Any natural or legal person may, under the conditions laid down in the first and second paragraphs, institute proceedings against an act addressed to that person or which is of direct and individual concern to them, and against a regulatory act which is of direct concern to them and does not entail implementing measures".

Front Polisario has to be considered a legal person in accordance to their stable condition, structures, statutes and representation in international and national practice acting as a legal person. It has an individual interest in the effects of the Decision, and according to the general principle pacta teriis nec nocent nec prosunt, it makes the regulation annullable and contrary to International Law. Furthermore, the article 29 of Vienna Convention on the Law of Treaties stated that "Unless a different intention appears from the treaty or is otherwise established, a treaty is binding upon each party in respect of its entire territory".

Due to the special condition of the territory of Western Sahara, in order to fully respect the responsibilities under the UN Charter the EU needs to be much more clear in explicitly eliminating the territory of Western Sahara for several reason, that can be took from UNSCR 1514 (15) or General Assembly Resolution 2625 (XXV) and the enshrined ius cogens rule of self-determination.

The Judgment was also fronting International Law basic resolutions, as the UNGAR 1803 about Permanent Sovereignty over natural resources when considered that "foreign investment agreements freely entered into by or between sovereign States shall be observed in good faith; States and international organizations shall strictly and conscientiously respect the sovereignty of peoples and nations over their natural wealth and resources in accordance with the Charter and the principles set forth in the present resolution".

While the CJEU in its 2018 Judgment seems to leave no doubt about the need to understand the agreement leaving out the territory of Western Sahara, one might wonder if the European Union is violating the rules of occupation by not expressly excluding Western Sahara territory from the agreement. Thus, the occupational standards studied reveal that mere collaboration with the occupying power could constitute a violation of the EU obligations to cooperate, so that the occupation situation comes to an end. In the same vein, the ICJ ruled in the Opinion on the Wall and UNSCR on Western Sahara 2152 (2014) or 2218 (2015). 


\section{Palestine products in the EU: a Thread to human Rights?}

The EU has repeatedly condemned the occupation of the territory by Israel, not recognizing any sovereignty over the settlements, which until date already dominate $45 \%$ of the territory. This would be the accomplishment on the very first obligation by the European Union in these cases, recognising there is a territory pending the exercise of self-determination of people by not recognising there is any sovereignty of the occupying power. In addition, after the adoption of the General Assembly Resolution in which nonmember observer State status ${ }^{20}$ was granted to Palestine, and its recognition by those of 130 States of the International Community, the European Parliament declared in 2014 that it "Supports in principle recognition of Palestinian statehood"21, in addition to showing its deep concern about the situation in the region and stressing that the only possible solution to the conflict is the coexistence of two States, Israel and Palestine.

Although there are erga omnes obligations, the European Union has maintained economic relations with the occupying power, Israel, who has received grants in different cooperation programs. In fact, as the Union itself acknowledges "The EU is Israel's main trading partner and receives $35.3 \%$ of Israel's total exports ( $\$ 16.8$ billion) followed by the US. (32.1\%)". ${ }^{22}$ Likewise, a solid relationship has been built based on the association agreement between them. ${ }^{23}$ An example is the scientific cooperation that has come to include Israel as the only non-European partner of the Horizon 2020 R\&D strategy.

The question is whether the consolidation of economic and commercial relations between the European Union and Israel, viewed in itself, means a breach of the rules of international law that impose on the European Union an attitude of "not contributing" to such occupation.

Traditionally it has been argued that the obligation not to contribute to the occupation extends only to trade with the occupied territory, however, it is true that the establishment of high-level economic and diplomatic relations with a State that is violating essential norms of International Law could imply incoherence with respect to the values and principles that the subjects of International Law in general are called to respect contained in Resolution 2625 (XXV) and in the Charter of the United Nations.

In addition, it remains to be determined whether trade between the two does not, considered in itself, constitute a support for the activities that the occupying power develops in the occupied territory, even when there is no illegitimate use of the territory natural resources. Indeed, the obligations that International Law imposes on the subjects

\footnotetext{
${ }^{20} \mathrm{~A} / \mathrm{RES}$ 67/19, Status of Palestine in the United Nations, https://undocs.org/A/RES/67/19.

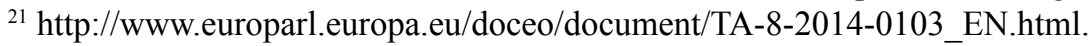

${ }^{22}$ European Commission, Press Release, 19/02/2018, http://europa.eu/rapid/press-release_MEMO-95127 es.htm.

23 EURO-MEDITERRANEAN AGREEMENT establishing an association between the European Communities and their Member States, of the one part, and the State of Israel, of the other part, DOUE 21.06.2000, L 147/03.
} 
in cases of Non-Self-Governing and occupied territories have to do with the objective of achieving a cessation of the occupation situation, which leads us to assume that only the blocking of the occupying power can be effective in stopping said breach of international standards.

Nevertheless, the EU has imposed some limits the trade with Israel when its comprises products originated in Palestinian territories. Firstly, considering the 2013 EU Guidelines on the eligibility of Israel entities and their activities in the territories occupied by Israel since June $1967^{24}$, whose aim is to "ensure the respect of EU positions and commitments in conformity with international law on the non-recognition by the EU of Israel's sovereignty over the territories occupied by Israel since June 1967'. As a result of this instrument, Israel is only eligible for grants, prizes and financial instrument within pre-1967 borders. Besides, the Guideline hold a comprehensive perspective, stating that "in order to clearly articulate EU commitments under international law, taking into account relevant EU policies and positions, the Commission will also endeavour to have the content of these guidelines reflected in international agreements or protocols thereto or Memoranda of Under standing with Israeli counterparts or with other parties".

But also the CJEU has imposed restrictions to trade with Israel. One of the best examples is the Brita case ${ }^{25}$. In this case the CJEU considered that the products originated in Palestinian territories fell outside the Agreement territorial scope ${ }^{26}$, stating that "both from Article 17 of the EC-Israel Protocol and from Article 15 of the EC-PLO Protocol, that proof of origin must be produced in respect of products originating in the territories of the contracting parties if they are to qualify for the preferential treatment. That requirement of valid proof of origin issued by the competent authority cannot be considered to be a mere formality that may be overlooked as long as the place of origin is established by means of other evidence". Not considering this proof a mere formality is essential to certify the validity of the Agreement and the effectivity of its clauses, as considered by the CJEU. In this scenario, the obligation concerning the European Union to not contribute to the occupation would be infringed if the Agreement is being applied without a consistent and rigorous approach.

Ten years after the Brita case, another issue of note is the case C-363/18 ${ }^{27}$, request for a preliminary ruling under Article 267 TFEU from the Conseil d'État (Council of

\footnotetext{
${ }^{24}$ Guidelines on the eligibility of Israeli entities and their activities in the territories occupied by Israel since June 1967 for grants, prizes and financial instruments funded by the EU from 2014 onwards (2013/C 205/05), DOUE 19.07.2013. C/205/09.

${ }^{25}$ Case C-38/08.

${ }^{26}$ Considering, among others, para. 52, "Accordingly, to interpret Article 83 of the EC-Israel Association Agreement as meaning that the Israeli customs authorities enjoy competence in respect of products originating in the West Bank would be tantamount to imposing on the Palestinian customs authorities an obligation to refrain from exercising the competence conferred upon them by virtue of the abovementioned provisions of the EC-PLO Protocol. Such an interpretation, the effect of which would be to create an obligation for a third party without its consent, would thus be contrary to the principle of general international law, 'pacta tertiis nec nocent nec prosunt', as consolidated in Article 34 of the Vienna Convention.

${ }^{27}$ Case C-363/18.
} 
State), France ${ }^{28}$. It concerns to the interpretation of Regulation (EU) 1169/2011 on the provision of food information to consumers, and its relations to other EU amended norms $^{29}$. In the Regulation No 1169/2011, the area of consumer's choice also include as a element to be considerate by the consumers the ethical reasons. This means that people should have the right to choose the food in order also to prevent any practices that may mislead the consumer. In this context, products must, among other considerations, provide the information of the country of origin.

In the Judgement, the CJEU considered that this regulation "must be interpreted as meaning that foodstuffs originating in a territory occupied by the State of Israel must bear not only the indication of that territory but also, where those foodstuffs come from an Israeli settlement within that territory, the indication of that provenance" ${ }^{\prime 30}$. Also, it has to be included the Interpretative Notice on indication of origin of goods from the territories occupied by Israel since June $1967^{31}$, which indicates the exact denomination that products should contain when originate in the territories occupied by Israel (Golan Heights, Gaza Strip and the West Bank and East Jerusalem). The Note makes clear that the purpose is to "ensure the respect of Union positions and commitments in conformity with international law on the non-recognition by the Union of Israel's sovereignty over the territories occupied by Israel since June 1967’.

Case C-363/18 has been considered in conjunction with the C-104/16 P Council v. Polisario Front, expressing accordingly with this Judgement that under International Law both territories have a separate and different status from the State being under jurisdiction ${ }^{32}$, stating that "under the rules of international humanitarian law, these territories are subject to a limited jurisdiction of the State of Israel, as an occupying power, while each has its own international status distinct from that of that State" 33 and recognising the right to selfdetermination of the territories, as stated in the International Court of Justice Advisory Opinion on the Wall ${ }^{34}$.

In this case, the products were originated in Israeli settlements located in Palestinian territories. It is interesting the Court examination about the policy of population transfer

\footnotetext{
${ }^{28}$ The request has been made in proceedings between, on the one hand, Organisation juive européenne and Vignoble Psagot Ltd and, on the other hand, the ministre de l'Économie et des Finances (the French Minister for the Economy and Finance) in relation to the legality of a notice concerning the indication of origin of goods originating in the territories occupied by the State of Israel since June 1967.

${ }^{29}$ Regulations (EC) No 1924/2006 and (EC) No 1925/2006 of the European Parliament and of the Council, and repealing Commission Directive 87/250/EEC, Council Directive 90/496/EEC, Commission Directive 1999/10/EC, Directive 2000/13/EC of the European Parliament and of the Council, Commission Directives 2002/67/EC and 2008/5/EC and Commission Regulation (EC) No 608/2004 (OJ 2011 L 304.

${ }^{30}$ Case 363/18, Judgement, para 21.

${ }^{31}$ Interpretative Notice on indication of origin of goods from the territories occupied by Israel since June $1967(2015 /$ C 375/05)

${ }^{32}$ Case 363/18, Judgement, para 31.

${ }^{33}$ Ibídem., para. 34.

${ }^{34}$ Advisory Opinion of 9 July 2004, Legal Consequences of the Construction of a Wall in the Occupied Palestinian Territory (ICJ Reports 2004, p. 136).
} 
conducted by Israel and the consideration on these facts as a violation of Genève Conventions in the area of International Humanitarian Law. The Court referred to the Article 3 (5) TEU, and the obligation of the EU to "contribute to the strict observance of International Law, including the principles of the United Nations Charter"35.

For that matter, the Court considers quite rightly that "the fact that a foodstuff comes from a settlement established in breach of the rules of international humanitarian law may be the subject of ethical assessments capable of influencing consumers' purchasing decisions" 36 , finally concluding that "foodstuffs originating in a territory occupied by the State of Israel must bear not only the indication of that territory but also, where those foodstuffs come from a locality or a group of localities constituting an Israeli settlement within that territory, the indication of that provenance" 37 .

This sentence is of an enormously relevance due to the fact that the practice and legal precedents have been set into place, and this would be analogously applied to the case of Western Sahara.

\section{Conclusion}

Human rights have been promptly incorporated to the legal framework governing trade and external action in the EU. Tools such as GSP or the bilateral agreements, offer the opportunity to monitor the promotion of human rights by the EU with its commercial partners. Even though, the restriction to certain products, should be extended to those whose economic benefits favoured illegal situation as occupation.

The need imposed for labelling products, both of Palestinian products and of those from Israeli settlements in occupied territory is laudable on the part of the European Union to carry out control over trade with an occupying power in accordance with and human rights approach. Nevertheless, its close diplomatic and economic relations with Israel are not reconcilable with the obligation to not provide help or assistance to the occupation. Therefore, in this case there is a partial follow-up of the obligations incumbent on the EU with respect to a Non-Self-Governing territories.

In the case of Western Sahara, it is very difficult to understand how the almost consolidated policies in the territory of Palestine have not been followed. In this case, there have been no sanctions, embargo or limits on investments, despite a situation of extreme vulnerability of the Saharawi population in the territories managed by the occupying power and serious human rights violations.

Likewise, the drafting of an interpretative note on the indication of the origin of the goods from the occupied Saharawi territory is necessary and urgent, just as this document exists with respect to the Palestinian territories.

\footnotetext{
${ }^{35}$ Case 363/18, Judgement, para 48.

${ }^{36}$ Ibídem., para. 56.

${ }^{37}$ Ibídem., para 60.
} 
In the trade agreements reached with Morocco, it is urgent to make specific observations on the exclusion of the Western Sahara territory as well as specific human rights provisions.

\section{REFERENCES}

CASSESE, A., (2005), International Law, Oxford University Press.

DER-CHIN HORNG, (2003), "The Human Rights Clause in the European Union's External Trade and Development Agreements", European Law Journal, 9, 5, (2003) 677-701. https://doi.org/10.1046/j.1468-0386.2003.00198.x

GASHI, K.; MUSLIU, V.; ORBIE, J., (2017), “Mediation Through Recontextualization: The European Union and the Dialogue Between Kosovo and Serbia, European Foreign Affair Review", vol. 22, no 4, 533-550.

GÓMEZ COSARNAU, A., (2003), "El uso de la cláusula democrática y de derechos humanos en las relaciones exteriores de la Unión Europea”, Observatori de Política Exterior Europea Working Paper, no 39.

JANER TORRENS, J. D., (2017), "Sistema de Preferencias Generalizadas y promoción de los derechos humanos en la acción exterior de la Unión Europea”, in MARTÍNEZ CAPDEVILLA, C.; MARTÍNEZ PÉREZ, E., Retos para la Acción Exterior de la Unión Europea, Tirant lo Blanch, 631-652.

JULIÁ BARCELÓ, M., (2019), “La proyección Exterior De La Identidad Europea: Política Comercial Común Y Condicionalidad En Materia De Derechos Humanos", Cuadernos Europeos De Deusto, n. ${ }^{\circ} 02$ (febrero), 287-308. https://doi. org/10.18543/ced-02-2019pp287-308

KASSOTI, E., (2017), “The Legality under International Law of the EU's Trade Agreements covering Occupied Territories: A Comparative Study of Palestine and Western Sahara", CLEER PAPERS 2017/3.

KASSOTI, E., (2018), "The EU and Western Sahara: An Assessment of Recent Developments", European Law Review, 5, 751-769.

KOSKENIEMI, M.; LEINO, P., (2002), "Fragmentation of International Law? Postmodern Anxieties", Leiden Journal of International Law, vol. 15, issue 3, 553-579. https:// doi.org/10.1017/S0922156502000262

LENAERTS, K., (2012), "Exploring the Limits of the EU Charter of Fundamental Rights", European Constitutional Law Review, 8, 3, (2012) 375-403. https://doi. org/10.1017/S1574019612000260

PAYANDEH, M., (2015), "Fragmentation within International Human Rights Law", en Mads Andenas/Eirik Bjorge (eds.), A Farewell to Fragmentation: The ICJ's Role in the Reassertion and Convergence of International Law, Cambridge University Press. 
VAN DER LOO, G., (2018), “The Dilemma of the EU's Future Trade Relations with Western Sahara Caught between strategic interests and international law?", CEPS, Commentary, Thinking ahead for Europe, 20 April 2018

VAN ELSUWEGE, P., (2017), "Legal Creativity in EU External Relations: The Stabilization and Association Agreement Between the EU and Kosovo", European Foreign Affairs Review, vol 22, nº 3, 393-409.

WAHLQVIST, T, (2021), Trade agreements with occupying powers: A case study of the EU external action in Western Sahara from a social justice perspective, Uppsala University.

WISEHART, D., (2014), "The Crisis in Ukraine and the Prohibition of the Use of Force: A Legal Basis for Russia’s Intervention?” EJIL: Talk!, 4 March 2014.

WRANGE, P., (2015), Occupation/Annexation of a Territory: Respect for International Humanitarian Law and Human Rights and Consistent EU Policy, Study undertaken at the Request of the European Parliament 30 June 2015, PE 534.995. EU Strategic Framework and Action Plan on Human Rights and Democracy, Luxembourg, 25 June 2012 11855/12.

Received: February $4^{\text {th }} 2021$

Accepted: July $25^{\text {th }} 2021$ 